\title{
Comparison of Carbon Dioxide Emissions Intensity of Steel Production in China, Germany, Mexico, and the United States
}

\author{
Ali Hasanbeigi, ${ }^{a}$ Marlene Arens, ${ }^{\mathrm{b}}$ Jose Carlos Rojas Cardenas, ${ }^{\mathrm{a}, \mathrm{c}}$ Lynn Price, ${ }^{\mathrm{a}}$ Ryan Triolo ${ }^{\mathrm{a}}$ \\ ${ }^{a}$ China Energy Group, Energy Analysis and Environmental Impacts Division, Lawrence Berkeley \\ National Laboratory, Berkeley CA, U.S.A. \\ ${ }^{\mathrm{b}}$ Fraunhofer Institute for Systems and Innovation Research ISI, Karlsruhe, Germany \\ ${ }^{c}$ Department of Engineering, National Autonomous University of Mexico, Mexico City, Mexico
}

\begin{abstract}
Production of iron and steel is an energy-intensive manufacturing process. The goal of this study was to develop a methodology for accurately and more fairly comparing the energy-related carbon dioxide $\left(\mathrm{CO}_{2}\right)$ emissions intensity of steel production in different countries and to demonstrate the application of this methodology in an analysis of the steel industry in China, Germany, Mexico, and the U.S. Our methodology addresses the industry's boundary definition, conversion factors, and industry structure. The results of our analysis show that, for the entire iron and steel production process, the base-case (2010) $\mathrm{CO}_{2}$ emissions intensity was 2,148 kilogram $(\mathrm{kg}) \mathrm{CO}_{2} /$ tonne crude steel in China, 1,708 $\mathrm{kg} \mathrm{CO}_{2} /$ tonne crude steel in Germany, 1,080 $\mathrm{kg} \mathrm{CO}_{2}$ /tonne crude steel in Mexico, and 1,736 $\mathrm{kg} \mathrm{CO}_{2} /$ tonne crude steel in the U.S. One of the main reasons that Mexico has the lowest $\mathrm{CO}_{2}$ emissions intensity is Mexico's large share of steel production using electric arc furnaces (EAFs) (69.4\%). EAF steel production has lower $\mathrm{CO}_{2}$ emissions intensity than production using blast furnaces/basic oxygen furnaces. China, by contrast, has the smallest share of EAF production among the four countries $-9.8 \%$ in the basecase year 2010. In one scenario, we applied the Chinese share of EAF production to the other three case-study countries; the result was an increase in $\mathrm{CO}_{2}$ emissions intensity of steel production of $19 \%\left(2,036 \mathrm{kgCO}_{2} /\right.$ tonne crude steel) in Germany, $92 \%\left(2,074 \mathrm{kgCO}_{2} /\right.$ tonne crude steel) in Mexico, and $56 \%\left(2,703 \mathrm{kgCO}_{2} /\right.$ tonne crude steel) in the U.S. compared to these countries' base-case analyses. In another scenario, we applied the Chinese national average grid electricity $\mathrm{CO}_{2}$ emissions factor from 2010, which is the highest emissions factor among the four countries, to the other three countries. In that scenario, the $\mathrm{CO}_{2}$ emissions intensity of steel production increased by $5 \%$ in Germany, $11 \%$ in Mexico, and $10 \%$ in the U.S.
\end{abstract}

Keywords: Carbon dioxide intensity; Iron and steel industry; Energy intensity

\section{Introduction}

\subsection{Background}

Iron and steel production is an energy and carbon dioxide $\left(\mathrm{CO}_{2}\right)$ intensive manufacturing process. In the four countries investigated in this paper, two types of steel production dominate: blast furnace/basic oxygen furnace $(\mathrm{BF} / \mathrm{BOF})$ and electric arc furnace $(\mathrm{EAF})$ production. $\mathrm{BF} / \mathrm{BOF}$ production uses iron ore to produce steel. The reduction of iron ore to iron in a BF is the most energy-intensive process within the steel industry. EAF production re-melts scrap to produce steel. BF/BOF production is more energy intensive and emits more $\mathrm{CO}_{2}$ than EAF production (Aichinger and Steffen 2006). 
This paper describes a follow-up study to Hasanbeigi et al. (2011). In the 2011 report, we compared the energy intensity of steel production in China and the U.S. In the current paper, we have modified the methodology developed for the previous report so that we can now compare the energy-related $\mathrm{CO}_{2}$ emissions intensity of the iron and steel industry in four countries: China, Germany, Mexico, and the U.S.

As Tanaka (2008) pointed out, "energy consumption and energy intensity are often estimated based on different definitions of an industry's boundaries, making comparison at best difficult, at worst invalid." The goal of this updated study is to modify the methodology developed in our previous study so that we can use it to accurately compare the $\mathrm{CO}_{2}$ intensity $\left(\mathrm{CO}_{2}\right.$ emissions per unit of crude steel produced) of steel production in China, Germany, Mexico, and the U.S. Our methodology provides boundary definitions, conversion factors, and physical-versus-economic $\mathrm{CO}_{2}$ intensity indicators to develop a common framework for comparing steel industry $\mathrm{CO}_{2}$ emissions in these four countries. More details about the data sources, data preparation, and assumptions used in the current study are described in Hasanbeigi et al. (2011) and Appendices 1 and 2 to this paper.

Previous comparisons of international steel industry energy use and energy or $\mathrm{CO}_{2}$ intensity have employed a range of methods. Worrell et al. (1997) found that physical indicators of steel sector energy and $\mathrm{CO}_{2}$ intensity provided a more robust basis for comparison among countries than economic indicators. Within the range of analyses based on physical factors, a variety of study boundaries, units of analysis, and conversion factors have been used. For example, Worrell et al. (1997) use crude steel production as their unit of analysis whereas Stubbles (2000) calculated energy use and $\mathrm{CO}_{2}$ intensity per ton of shipped steel. Likewise, whereas Andersen and Hyman (2001) include coke-making energy use, Kim and Worrell (2002) omit coke making from their respective definitions of the industry boundary.

A review of comparison studies shows that boundary and conversion factor assumptions are not always explicitly stated and appear to vary widely, especially for characterizing imported or offsite produced inputs. Consensus has yet to form on boundaries and conversion factors for comparison of international steel production $\mathrm{CO}_{2}$ intensity, resulting different studies producing widely disparate results that are difficult to interpret and compare. For example, Tanaka (2008) presents a case study on Japan's iron and steel industry that illustrates the critical role of proper boundary definitions for a meaningful comparison of $\mathrm{CO}_{2}$ intensity for the steel industry. Depending on the boundaries set for the analysis, the energy use per tonne of crude steel that Tanaka calculated ranges from 16 to 21 gigajoules (GJ), which results in similar variation in $\mathrm{CO}_{2}$ intensity. In addition, Farla and Blok (2001) studied the data for physical-energy and $\mathrm{CO}_{2}$ intensity indicators in the steel industry and found mistakes in reported energy data, which make reliable international comparisons of countries even more difficult. Furthermore, different international greenhouse gas (GHG) accounting and reporting frameworks have set different boundaries for the iron and steel industry. Figure 1 shows the different boundary definitions in international guidelines for GHG emissions of BF integrated steel plants (Tanaka 2008). It is clear that $\mathrm{CO}_{2}$ intensity calculated using different guidelines - Intergovernmental Panel Climate Change (IPCC), European Union (EU) Emissions Trading System (ETS), or World Resources 
Institute/World Business Council on Sustainable Development (WRI/WBCSD) - cannot be compared to one another.

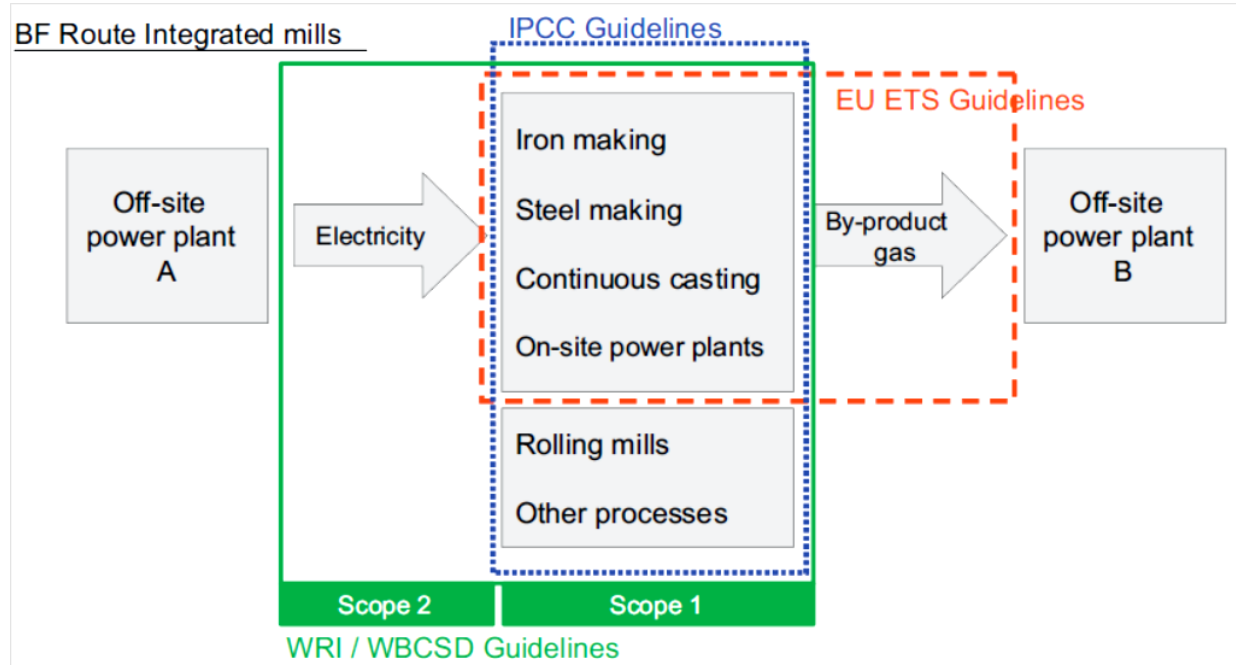

Figure 1. Different boundary definitions in international guidelines for calculating GHG emissions of BF integrated steel plants (Tanaka 2008)

Policy makers often seek a single $\mathrm{CO}_{2}$ intensity value for steel production in individual countries to aid in decision-making related to GHGs and competitiveness. However, it is difficult to provide a single $\mathrm{CO}_{2}$ intensity value for steel production in an individual country that can then be used to compare $\mathrm{CO}_{2}$ intensity among countries. The above analysis illustrates that such a single indicator does not provide enough information to fully explain country-specific conditions.

\subsection{Overview of the iron and steel industry in China, Germany, Mexico, and the U.S.}

China is a developing country currently in the process of industrialization. The Chinese iron and steel industry has grown rapidly along with the national economy. In 1996, China's crude steel production surpassed 100 million metric tonnes (Mt). Since then, steel production in China has continued to increase rapidly, and for 14 continuous years China has been the world's largest crude steel producer. The average annual growth rate of crude steel production was $18.5 \%$ between 2000 and 2009. Steel production in 2010 was $637 \mathrm{Mt}$ (worldsteel 2013), representing $46.6 \%$ of world production that year. China's steel industry is a significant contributor to global $\mathrm{CO}_{2}$ emissions.

Germany's crude steel production increased from 38 Mt in1990 to a peak of 48 Mt in 2007, after which production dropped to $44 \mathrm{Mt}$ in 2010 (worldsteel 2013). The increase was the result of increasing production of steel in EAFs while production using the BF/BOF process remained almost constant at an annual total of approximately $30 \mathrm{Mt}$ of hot metal (WV Stahl 2013). The German iron and steel industry has continuously reduced its consumption of coke in the BF by $50 \%$ over the last six decades by employing efficiency measures such as top pressure recovery turbine (TRT), pulverized coal injection, use of oxygen, etc. (Aichinger et al. 2006). 
Steel production in Mexico grew at 3.3\% per year from 1990 to 2010, with important downturns in 2001 and 2008 associated with economic conditions. In 2010, the Mexican iron and steel industry produced $16.87 \mathrm{Mt}$ of steel that accounted for $1.5 \%$ of the national gross domestic product and $8.4 \%$ of the manufacturing gross domestic product (INEGI 2012). Steel production using EAFs accounted for the $69.4 \%$ of the total crude steel production in Mexico in 2010; the remaining 30.6\% was made in BOFs (INEGI 2012). Mexican iron and steel production consumed more energy than any other industrial use in the country in 2010, 197.25 petajoules (PJ), representing 14.3\% of total final industrial energy consumption (SENER 2014). Most of the steel in Mexico is produced in medium-large facilities. Four major steel companies in Mexico produced $79.5 \%$ of the total crude steel manufactured in the country in 2010 . These companies also represent $57 \%$ of the installed capacity, with plants ranging from 1 to $5.3 \mathrm{Mt} /$ year (USGS 2011a).

In the U.S., steel production peaked in 1973 at 137 Mt (USGS 2010a). After 2000, the level of U.S. steel production hovered below $100 \mathrm{Mt}$, with total production of $98 \mathrm{Mt}$ in 2006 . U.S. steel production dropped to $56 \mathrm{Mt}$ in 2009, a $19 \mathrm{Mt}$ decrease in one year (USGS 2010b), but rebounded to about $80 \mathrm{Mt}$ in 2010 (worldsteel 2013). The $\mathrm{CO}_{2}$ intensity and energy efficiency of U.S. steel production has continually improved because of industry restructuring during the 1970s and 1980s, an increase in production of steel in EAFs, adoption of continuous casting, use of direct hot rolling, and feedstock process improvements (Ruth et al. 2000, Tornell 1997).

Based on Worldsteel.org statistics (worldsteel, 2015), in 2014, China alone accounted for about $50 \%$ of world steel production. The U.S. and Germany are in the $4^{\text {th }}$ and $7^{\text {th }}$ place in world steel production in the same year. Mexico, while being in the $13^{\text {th }}$ place for steel production in the world, it is the $3^{\text {rd }}$ largest steel producing country in the American continent (after U.S.A and Brazil). Therefore, countries studies in this paper are among the largest steel producing countries in the world.

\section{Methodology}

This study uses a bottom-up, physical-based methodology to compare the $\mathrm{CO}_{2}$ intensity of crude steel production in China, Germany, Mexico, and the U.S. in 2010. The year 2010 was chosen to maximize the availability of comparable steel sector data. However, data published in these four countries are not always consistent in terms of analytical scope, conversion factors, and information on adoption of $\mathrm{CO}_{2}$-abatement technologies, as we discuss below.

\subsection{Boundary definitions}

In this study, the boundary of the iron and steel industry is defined to include all of the following: coke making, pelletizing, sintering, iron making, steel making, steel casting, hot rolling, cold rolling, and processing such as galvanizing or coating (Figure 2). This boundary definition is used for calculating $\mathrm{CO}_{2}$ emissions and $\mathrm{CO}_{2}$ intensity in the four case study countries. This study takes net imported pig iron, direct-reduced iron (DRI), pellets, lime, oxygen, as well as ingots, blooms, billets, and slabs into account by adding the energy-related $\mathrm{CO}_{2}$ emissions for production of these products to the total energy-related $\mathrm{CO}_{2}$ emissions of the steel industry. 
This study does not include $\mathrm{CO}_{2}$ emissions of ferro-alloy production. Because ferro-alloy production is represented in overall steel industry energy statistics in China as a separate industry category (category 3240 within overall category 32), it was possible to subtract ferro-alloy contributions from the overall energy use for iron and steel production before we calculated $\mathrm{CO}_{2}$ emissions. Similarly ferro-alloy production is reported separately in the U.S. Manufacturing Energy Consumption Survey, so energy consumed for this purpose is not included in U.S. iron and steel industry energy consumption value. In German statistics, ferro-alloy production is included in the iron and steelmaking processes; however, Germany mostly imports ferro-alloys from other countries, mainly China, India, and South Africa, so German ferro-alloy production is minimal, carried out by only one small company. Therefore, the influence of domestic ferroalloy production on the $\mathrm{CO}_{2}$ intensity in Germany is very small. In Mexico, ferro-alloy production is not reported separately. Appendix A explains how we estimated and subtracted the contribution of ferro-alloy production in Mexico.

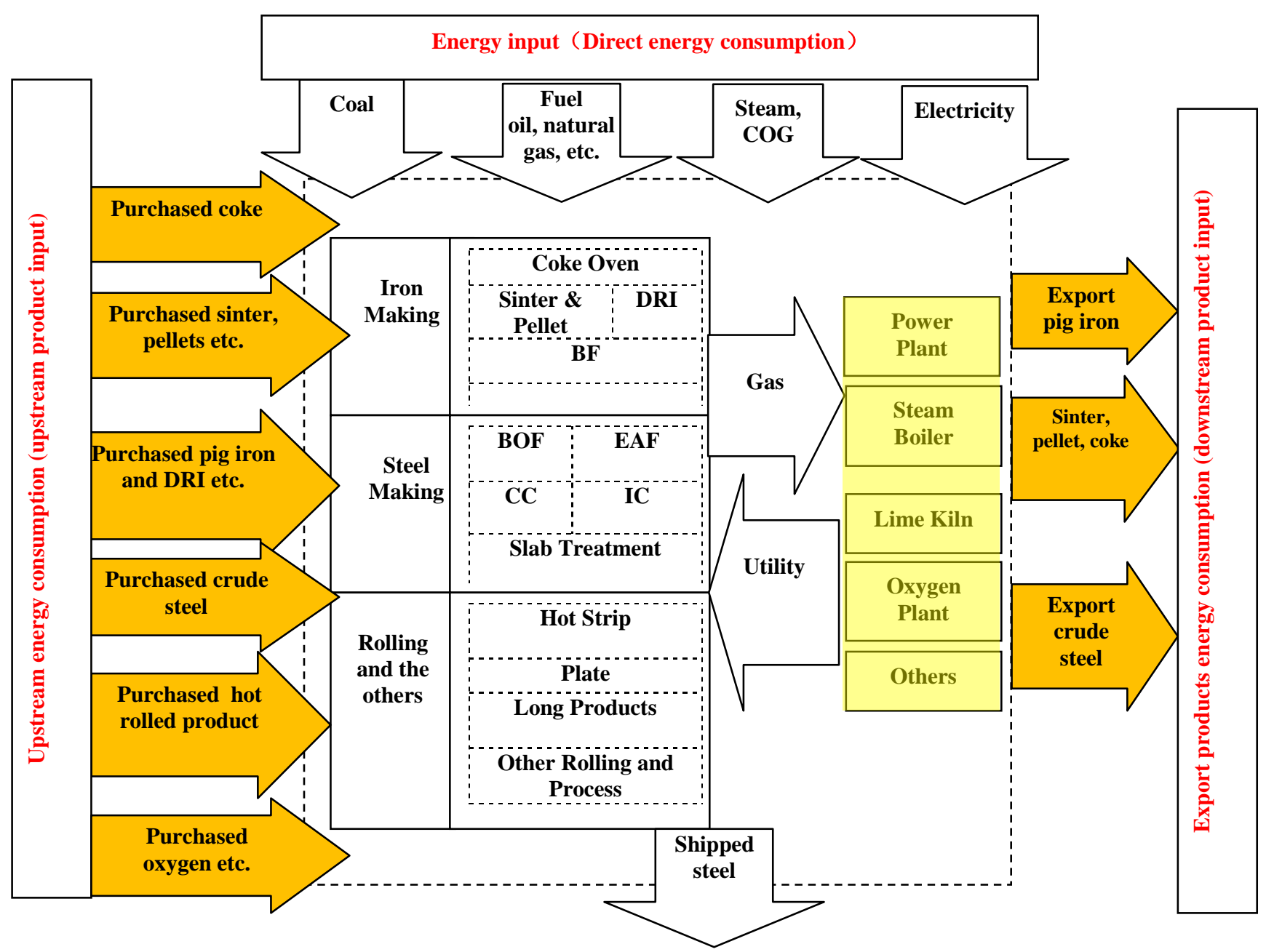

Figure 2. Flow chart of iron and steel sector boundaries used in this study

Note: BF: blast furnace; BOF: basic oxygen furnace; EAF: electric arc furnace; DRI: direct reduced iron; CC:

continuous casting; IC: investment casting 
There are a few special considerations associated with accounting for $\mathrm{CO}_{2}$ emissions from coke production within the iron and steel industry. For China and the U.S., this analysis includes the total coal input used as a feedstock for coke making as well as coal used as fuel in other parts of the steel-making process. Only net imported coke (either produced in other domestic industries or imported from other countries) is included as a source of input energy to the iron and steel industry. Net imported coke is total imported coke minus total exported coke. The energy value of the coke produced in the coke-making process within the iron and steel industry and used in the iron-making process is not included because the coal initially used to produce the coke is already accounted for within the boundary definition of the entire industry. Because German statistics exclude coke ovens, we treat coke as an energy input for Germany and the energy used for its production is treated as a purchased energy carrier. This study does not count the coke trade that occurs within the boundary of the industry because the total coal input to the industry is already taken into account. This study accounts for net imported pig iron, DRI, pellets, lime, oxygen, as well as ingots, blooms, billets, and slabs by adding the energy-related $\mathrm{CO}_{2}$ emissions for production of these products to the total $\mathrm{CO}_{2}$ emissions associated with the energy input to the iron and steel industry. Because we do not have data for Germany on lime imported from outside of the boundary defined in this study, the contribution of imported lime to the $\mathrm{CO}_{2}$ intensity of steel production in Germany is not included.

In addition, this study does not include $\mathrm{CO}_{2}$ emissions associated with other energy-intensive products manufactured for the iron and steel industry (e.g., electrodes, refractories, etc.). These products could be included in a more extensive, life-cycle analysis study of the industry but are excluded here because the focus of this study is on iron and steel production. This approach mirrors that taken by Stubbles (2000). The current study also does not take into account the embodied energy and $\mathrm{CO}_{2}$ of the scrap used in the iron and steel industry or the $\mathrm{CO}_{2}$ emissions associated with mining. Finally, the energy-related $\mathrm{CO}_{2}$ emissions from further processing of steel by foundries are also excluded from this analysis.

\subsection{Conversion factors}

\subsubsection{Fuel conversion factors}

The country-specific net calorific value (NCV) conversion factors for different fuels for China, Germany, Mexico, and the U.S. were used to convert the physical quantities of fuels consumed to produce steel to energy values. In our previous analysis (Hasanbeigi et al. 2011), we developed a scenario in which we used the common International Energy Agency (IEA) NCVs of fuels for both countries to assess the effect of differences in country-specific NCVs of fuels on the energy-intensity results. We found that the effect is minimal and can be ignored. Therefore, in this paper we do not develop a scenario using IEA NCVs for both countries instead of country-specific NCVs. Detailed information on country-specific NCV conversion factors for different fuels for China and the U.S. can be found in Hasanbeigi et al. (2011), for Germany in Arens et al. (2012), and for Mexico in SENER (2012).

\subsubsection{Conversion factors for purchased fuels and auxiliary/intermediary products}

For this study, international average energy conversion factors are used for products that are purchased externally and imported or exported by the iron and steel industry. This is done because imported products can come from different countries and thus vary in the energy 
consumed during their production as a result of country-specific differences in production technology and energy structure. The energy conversion factors for external products in this study are provided by the World Steel Association (worldsteel) (worldsteel n.d., worldsteel 2008b). We first calculate the embodied energy in terms of electricity and fuel use of the net imported auxiliary/intermediary products (in megajoules per kilogram $[\mathrm{MJ} / \mathrm{kg}]$ ), then we multiply the electricity and fuel consumption by the respective assumed country-specific $\mathrm{CO}_{2}$ conversion factors to calculate the embodied energy-related $\mathrm{CO}_{2}$ in these materials.

Table 1 gives the energy conversion factors for purchased fuels and materials as well as imported auxiliary/intermediary products along with the share of electricity used for production of each product. The values provided by worldsteel are assumed to be the international average and are used for the base case in this study. The results of the calculation based on worldsteel conversion factors might be slightly different from the steel-industry $\mathrm{CO}_{2}$ intensity calculated for each country using exact conversion factors that take into account the countries origin of all the intermediary products and the $\mathrm{CO}_{2}$ intensity of the products in those countries. However, that calculation was not undertaken for this study.

Table 1. Conversion factors for purchased fuels and auxiliary/intermediary products

\begin{tabular}{|c|c|c|c|c|c|c|c|c|}
\hline & Coke $^{a}$ & $\begin{array}{l}\text { Pig } \\
\text { Iron }^{a}\end{array}$ & $\begin{array}{c}\text { Coal based } \\
\text { DRI }^{\mathrm{a}}\end{array}$ & $\begin{array}{l}\text { Gas based } \\
\text { DRI }^{\mathrm{a}}\end{array}$ & Pellets ${ }^{a}$ & $\begin{array}{l}\text { Crude } \\
\text { Steel }^{b}\end{array}$ & Lime $^{a}$ & Oxygen $^{a}$ \\
\hline & $\mathrm{MJ} / \mathrm{kg}$ & $\mathrm{MJ} / \mathrm{kg}$ & $\mathrm{MJ} / \mathrm{kg}$ & $\mathrm{MJ} / \mathrm{kg}$ & $\mathrm{MJ} / \mathrm{kg}$ & $\mathrm{MJ} / \mathrm{kg}$ & $\mathrm{MJ} / \mathrm{kg}$ & $\mathrm{kWh} * / \mathrm{m}^{3}$ \\
\hline $\begin{array}{l}\text { worldsteel factors (final } \\
\text { energy) }\end{array}$ & 3.7 & 19.8 & 17.0 & 13.4 & 2.1 & 16.5 & 4.1 & 0.7 \\
\hline
\end{tabular}

For the fuel use of the net imported auxiliary/intermediary products, we calculated the weighted average fuel $\mathrm{CO}_{2}$ emissions factor of the steel industry for each country, with a few exceptions as follows. For net imported coke, the $\mathrm{CO}_{2}$ conversion factor of the coking coal was used to calculate the $\mathrm{CO}_{2}$ emissions associated with the fuel use for producing the net imported coke. For the coal-based direct reduced iron (DRI), the $\mathrm{CO}_{2}$ conversion factor of "other bituminous coal" was used. For the net imported DRI in the U.S. (the type of DRI was not specified), we based our approach on Chukwuleke et al. (2009) and assumed that $85 \%$ of the DRI imported to the U.S. is natural gas based and $15 \%$ is coal based. We applied these shares and used the $\mathrm{CO}_{2}$ conversion factor of natural gas and other bituminous coal to calculate the $\mathrm{CO}_{2}$ emissions associated with fuel used to produce the net imported DRI to the U.S. For the $\mathrm{CO}_{2}$ emissions associated with the energy used for the rolling and finishing of imported ingots, blooms, billets, and slabs, we used the weighted average fuel $\mathrm{CO}_{2}$ emission factor of the "Steel Products from Purchased Steel" industry (North American Industry Classification System [NAICS] category 3312) because the energy used for rolling and finishing of imported crude steel products is reported under this industry category in the U.S. statistics. For the $\mathrm{CO}_{2}$ emissions associated with the energy used for net imported lime, we used the weighted average fuel $\mathrm{CO}_{2}$ emission factor of the "Lime" industry (NAICS category 327410).

\subsubsection{Carbon dioxide conversion factors}

The fuel $\mathrm{CO}_{2}$ conversion factors used for calculating $\mathrm{CO}_{2}$ emissions from energy consumption were taken from the 2006 IPCC Guidelines for National Greenhouse Gas Inventories (IPCC 2006). The fuel input to the steel industry reported in the statistics of each country was 
multiplied by the fuel $\mathrm{CO}_{2}$ conversion factors to calculate the energy-related $\mathrm{CO}_{2}$ emissions. Before these multiplications, the data were treated to conform to the boundary definition explained in Section 3.1. Table 2 shows the weighted average fuel $\mathrm{CO}_{2}$ emissions factors used in this study for each country. Table 3 shows the national average grid electricity $\mathrm{CO}_{2}$ emission factors used in our analysis for each country.

Table 2. Weighted average fuel $\mathrm{CO}_{2}$ emissions factors for the steel industry in 2010

\begin{tabular}{|c|c|c|}
\hline Item & $\begin{array}{c}\mathrm{CO}_{2} \text { emission factor } \\
(\mathrm{kg} \mathrm{CO} / \mathrm{GJ})\end{array}$ & $\begin{array}{l}\text { Source of data } \\
\text { used for the } \\
\text { calculation }\end{array}$ \\
\hline $\begin{array}{l}\text { China weighted avg. fuel } \mathrm{CO}_{2} \text { emissions factor } \\
\text { for the steel industry using China-specific fuel } \\
\text { NCVs }\end{array}$ & 101.07 & $\begin{array}{l}\text { NBS 2011; } \\
\text { IPCC } 2006\end{array}$ \\
\hline $\begin{array}{l}\text { Germany weighted avg. fuel } \mathrm{CO}_{2} \text { emissions } \\
\text { factor for the steel industry using Germany- } \\
\text { specific fuel NCVs }\end{array}$ & 93.14 & $\begin{array}{l}\text { UBA 2012a; } \\
\text { IPCC } 2006\end{array}$ \\
\hline $\begin{array}{l}\text { Mexico weighted avg. fuel } \mathrm{CO}_{2} \text { emissions } \\
\text { factor for the steel industry using Mexico- } \\
\text { specific fuel NCVs }\end{array}$ & 76.50 & $\begin{array}{l}\text { SENER 2012; } \\
\text { IPCC } 2006\end{array}$ \\
\hline $\begin{array}{l}\text { U.S. weighted avg. fuel } \mathrm{CO}_{2} \text { emissions factor } \\
\text { for the steel industry (NAICS category 331111) } \\
\text { using Energy Information Administration (EIA) } \\
\text { fuel NCVs }\end{array}$ & 96.96 & $\begin{array}{l}\text { U.S DOE/EIA } \\
2013 \mathrm{a} ; \text { IPCC } \\
2006\end{array}$ \\
\hline $\begin{array}{l}\text { U.S. weighted avg. fuel } \mathrm{CO}_{2} \text { emissions factor } \\
\text { for "Steel Products from Purchased Steel" } \\
\text { industry (NAICS category 3312) using EIA } \\
\text { fuel NCVs }\end{array}$ & 63.47 & $\begin{array}{l}\text { U.S DOE/EIA } \\
2013 \mathrm{a} ; \text { IPCC } \\
2006\end{array}$ \\
\hline $\begin{array}{l}\text { U.S. weighted avg. fuel } \mathrm{CO}_{2} \text { emissions factor } \\
\text { for the "Lime" industry (NAICS category } \\
\text { 327410) using EIA fuel NCVs }\end{array}$ & 89.65 & $\begin{array}{l}\text { U.S DOE/EIA } \\
2013 \mathrm{a} ; \text { IPCC } \\
2006\end{array}$ \\
\hline
\end{tabular}

Table 3. National average grid electricity $\mathrm{CO}_{2}$ emission factors in 2010

\begin{tabular}{|l|c|c|}
\multicolumn{2}{|c|}{ Country } & $\begin{array}{c}\text { Grid } \mathrm{CO}_{2} \text { emission factor } \\
\left(\mathrm{kgCO}_{2} / \mathrm{kWh}\right)\end{array}$ \\
\hline China & 0.80 & NBS 2011; IPCC 2006 \\
\hline Germany & 0.54 & UBA 2012b; IPCC 2006 \\
\hline Mexico & 0.51 & SENER 2012; IPCC 2006 \\
\hline U.S. & 0.58 & U.S. DOE/EIA 2012; IPCC 2006 \\
\hline
\end{tabular}

\subsection{Base year production, trade, and energy use data}

\subsubsection{Production and trade data}

Table 4 through Table 7 list production, exports, and imports of pig iron, DRI, crude steel, and steel products in China, Germany, Mexico, and the U.S., respectively, for the year 2010. 
Table 4. Production, imports, and exports of pig iron, DRI, crude steel, ingots, billets, and steel products in China,

\begin{tabular}{|l|r|r|r|r|r|}
\multicolumn{1}{|c}{ Product } & \multicolumn{2}{c}{ Production } & \multicolumn{2}{c|}{ Exports } & \multicolumn{2}{c|}{ Imports } & Net Imports & Used in industry \\
\hline Hot metal/Pig Iron & 595.60 & 0.71 & 0.87 & 0.16 & 595.77 \\
\hline DRI & 0.03 & 0.21 & 1.38 & 1.17 & 1.20 \\
\hline Crude Steel & 638.74 & - & - & - & - \\
\hline Ingots, Blooms, Billets, Slabs & - & 42.70 & 17.11 & -25.59 & - \\
\hline
\end{tabular}

Source: EBCISIY 2011

Table 5. Production and trade of pig iron, DRI, crude steel, ingots, billets, and steel products in Germany, 2010 (Mt)

\begin{tabular}{|l|r|r|r|r|r|}
\multicolumn{1}{c|}{ Product } & \multicolumn{1}{c}{ Production } & \multicolumn{1}{c}{ Exports } & \multicolumn{1}{c|}{ Imports } & Net Imports & Used in industry \\
\hline Sinter & 26.79 & 0.0 & 16.39 & 16.39 & 43.18 \\
\hline Hot metal/Pig Iron & 28.56 & 0.19 & 0.44 & 0.25 & 28.81 \\
\hline DRI & 0.50 & 0.03 & 0.33 & 0.31 & 0.81 \\
\hline Crude Steel & 43.83 & & & & \\
\hline Ingots, Blooms, Billets, Slabs & & 2.34 & 1.78 & -0.56 & \\
\hline
\end{tabular}

Source: WV Stahl 2013

Table 6. Production, imports, and exports of pig iron, DRI, crude steel, ingots, billets, and steel products in Mexico in $2010(\mathrm{Mt})$

\begin{tabular}{|c|c|c|c|c|c|}
\hline Product & Production & Exports & Imports & Net Imports & Used in industry \\
\hline Hot metal/Pig Iron & 4.71 & 0.0 & 0.23 & 0.23 & 4.93 \\
\hline DRI & 5.37 & 0.0 & 0.0 & 0.0 & 5.37 \\
\hline Crude Steel & 16.87 & & & & \\
\hline Ingots, Blooms, Billets, Slabs & & 1.41 & 0.32 & -1.09 & 15.78 \\
\hline
\end{tabular}

Source: INEGI 2012, SE 2012

Table 7. Production, imports, and exports of pig iron, DRI, crude steel, ingots, billets, and steel products in the U.S in $2010(\mathrm{Mt})$

\begin{tabular}{|l|r|r|r|r|r|}
\multicolumn{1}{c}{ Product } & \multicolumn{1}{c}{ Production } & \multicolumn{1}{c}{ Exports } & \multicolumn{1}{c|}{ Imports } & Net Imports & Used in industry \\
\hline Hot metal/Pig Iron & 26.80 & 2.22 & 3.78 & 1.56 & 28.36 \\
\hline DRI & 0.0 & 0.0 & 1.64 & 1.64 & 1.64 \\
\hline Crude Steel & 80.50 & - & - & - & - \\
\hline Ingots, Blooms, Billets, Slabs & - & 0.61 & 4.6 & 3.99 & - \\
\hline
\end{tabular}

Source: USGS 2011b

For calculating energy intensities, we used crude steel production as the denominator. However, we note that the casting, rolling, and finishing processes that happen after the crude steel production are also within the boundary of the analysis.

\subsubsection{Energy use and carbon dioxide emissions data}

The energy consumption and associated $\mathrm{CO}_{2}$ emissions of steel production were calculated according to the boundaries shown in Figure 2. Total energy use was adjusted for net trade in auxiliary and intermediate products. For a detailed explanation of energy data treatment and preparation for China and the U.S., see Hasanbeigi et al (2011). For an explanation of energy data for the German steel industry, see Appendix 1 and for Mexican steel industry, see Appendix 2. The energy consumption and $\mathrm{CO}_{2}$ emissions of net imported coke, pig iron, DRI, steel ingots 
and billets, lime, oxygen, etc. for China, Germany, Mexico, and the U.S. are presented in Tables $8-11$.

Table 8. Total energy consumption and $\mathrm{CO}_{2}$ emissions of China's steel industry production in 2010 based on study boundaries (net import is to the steel industry)

\begin{tabular}{|c|c|c|c|c|c|c|}
\hline \multirow[t]{2}{*}{ Component } & \multicolumn{2}{|c|}{ Electricity } & \multicolumn{2}{|c|}{ Fuel } & \multicolumn{2}{|c|}{ Total Final Energy } \\
\hline & $\begin{array}{c}\text { Use } \\
(\text { GWh })\end{array}$ & $\begin{array}{c}\mathrm{CO}_{2} \text { Emissions } \\
\left(1,000 \mathrm{t} \mathrm{CO}_{2}\right)\end{array}$ & $\begin{array}{l}\text { Use } \\
(\mathbf{T J})^{*}\end{array}$ & $\begin{array}{c}\mathrm{CO}_{2} \text { Emissions } \\
\left(1,000 \mathrm{t} \mathrm{CO}_{2}\right)\end{array}$ & $\begin{array}{l}\text { Use } \\
(\mathbf{T J})\end{array}$ & $\begin{array}{c}\mathrm{CO}_{2} \text { Emissions } \\
\left(1,000 \mathrm{t} \mathrm{CO}_{2}\right)\end{array}$ \\
\hline $\begin{array}{l}\text { Reported energy consumption (excluding } \\
\text { the energy use for production of } \\
\text { intermediary products given below) }\end{array}$ & $271,900.00$ & 216,432 & $10,674,171$ & $1,078,787$ & $11,653,011$ & $1,295,219$ \\
\hline $\begin{array}{l}\text { Energy used for the production of } \\
\text { purchased coke }\end{array}$ & 8,473 & 6,745 & 715,713 & 67,706 & 746,216 & 74,451 \\
\hline $\begin{array}{l}\text { Energy used for the production of net } \\
\text { imports of hot metal/pig iron }\end{array}$ & 27 & 21 & 3,186 & 322 & 3,281 & 343 \\
\hline $\begin{array}{l}\text { Energy used for the production of net } \\
\text { imports of steel ingots }\end{array}$ & 7 & 6 & 674 & 68 & 700 & 74 \\
\hline $\begin{array}{l}\text { Energy used for the production of net } \\
\text { exports of steel billets/slabs }\end{array}$ & 88 & 70 & 8,293 & 838 & 8,611 & 908 \\
\hline $\begin{array}{l}\text { Total energy consumption of steel } \\
\text { industry with embodied energy of net } \\
\text { imported/exported } \\
\text { auxiliary/intermediary products } \\
\text { included }\end{array}$ & 280,655 & 223,402 & $11,421,282$ & $1,149,542$ & $12,431,642$ & $1,372,944$ \\
\hline
\end{tabular}

* terajoules

Note 1: The negative values indicate that the energy used by export products was subtracted.

Note 2: There are no energy use data given separately for lime and pellets because the energy use for the production of these products is included in the reported energy consumption of the steel industry in China (first row of this table), and there is no import or export of these two products.

Table 9. Total energy consumption and $\mathrm{CO}_{2}$ emissions of Germany's steel industry production in 2010 based on study boundaries (net import is to the steel industry)

\begin{tabular}{|c|c|c|c|c|c|c|}
\hline \multirow[t]{2}{*}{ Component } & \multicolumn{2}{|c|}{ Electricity } & \multicolumn{2}{|c|}{ Fuel } & \multicolumn{2}{|c|}{ Total Final Energy } \\
\hline & $\begin{array}{c}\text { Use } \\
(\text { GWh })\end{array}$ & $\begin{array}{c}\mathrm{CO}_{2} \\
\text { Emissions } \\
\left(1,000 t \mathrm{CO}_{2}\right)\end{array}$ & $\begin{array}{l}\text { Use } \\
(\mathbf{T J})^{*}\end{array}$ & $\begin{array}{c}\mathrm{CO}_{2} \\
\text { Emissions } \\
\left(1,000 t \mathrm{CO}_{2}\right)\end{array}$ & $\begin{array}{l}\text { Use } \\
\text { (TJ) }\end{array}$ & $\begin{array}{l}\mathrm{CO}_{2} \\
\text { Emissions } \\
(\mathbf{1 , 0 0 0 t} \\
\left.\mathrm{CO}_{2}\right)\end{array}$ \\
\hline $\begin{array}{l}\text { Reported energy consumption (excluding } \\
\text { the energy use for production of } \\
\text { intermediary products given below) }\end{array}$ & 14,881 & 8,096 & 640,431 & 58,848 & 694,004 & 66,944 \\
\hline $\begin{array}{l}\text { Energy used for the production of } \\
\text { purchased coke and coke breeze }\end{array}$ & 485 & 264 & 38,434 & 4,112 & 40,179 & 4,376 \\
\hline $\begin{array}{l}\text { Energy used for the production of } \\
\text { purchased pellets }\end{array}$ & 351 & 191 & 30,971 & 2,846 & 32,236 & 3,037 \\
\hline $\begin{array}{l}\text { Energy used for the production of net } \\
\text { imported pig iron }\end{array}$ & 43 & 23 & 4,826 & 443 & 4,980 & 467 \\
\hline $\begin{array}{l}\text { Energy used for the production of } \\
\text { purchased DRI }\end{array}$ & 35 & 19 & 3,982 & 366 & 4,110 & 385 \\
\hline $\begin{array}{l}\text { Energy used for the production of } \\
\text { purchased crude steel }\end{array}$ & -217 & -118 & $-8,497$ & -781 & $-9,278$ & -899 \\
\hline $\begin{array}{l}\text { Energy used for the production of } \\
\text { purchased steam }\end{array}$ & -103 & -56 & $-4,021$ & -369 & $-4,390$ & -425 \\
\hline $\begin{array}{l}\text { Total energy consumption of steel } \\
\text { industry with embodied energy of net } \\
\text { imported/exported } \\
\text { auxiliary/intermediary products } \\
\text { included }\end{array}$ & 15,476 & 8,419 & 706,126 & 65,466 & 761,841 & $\mathbf{7 3 , 8 8 5}$ \\
\hline
\end{tabular}


Table 10. Total energy consumption and $\mathrm{CO}_{2}$ emissions of Mexico's steel industry production in 2010 based on study boundaries (net import is to the steel industry)

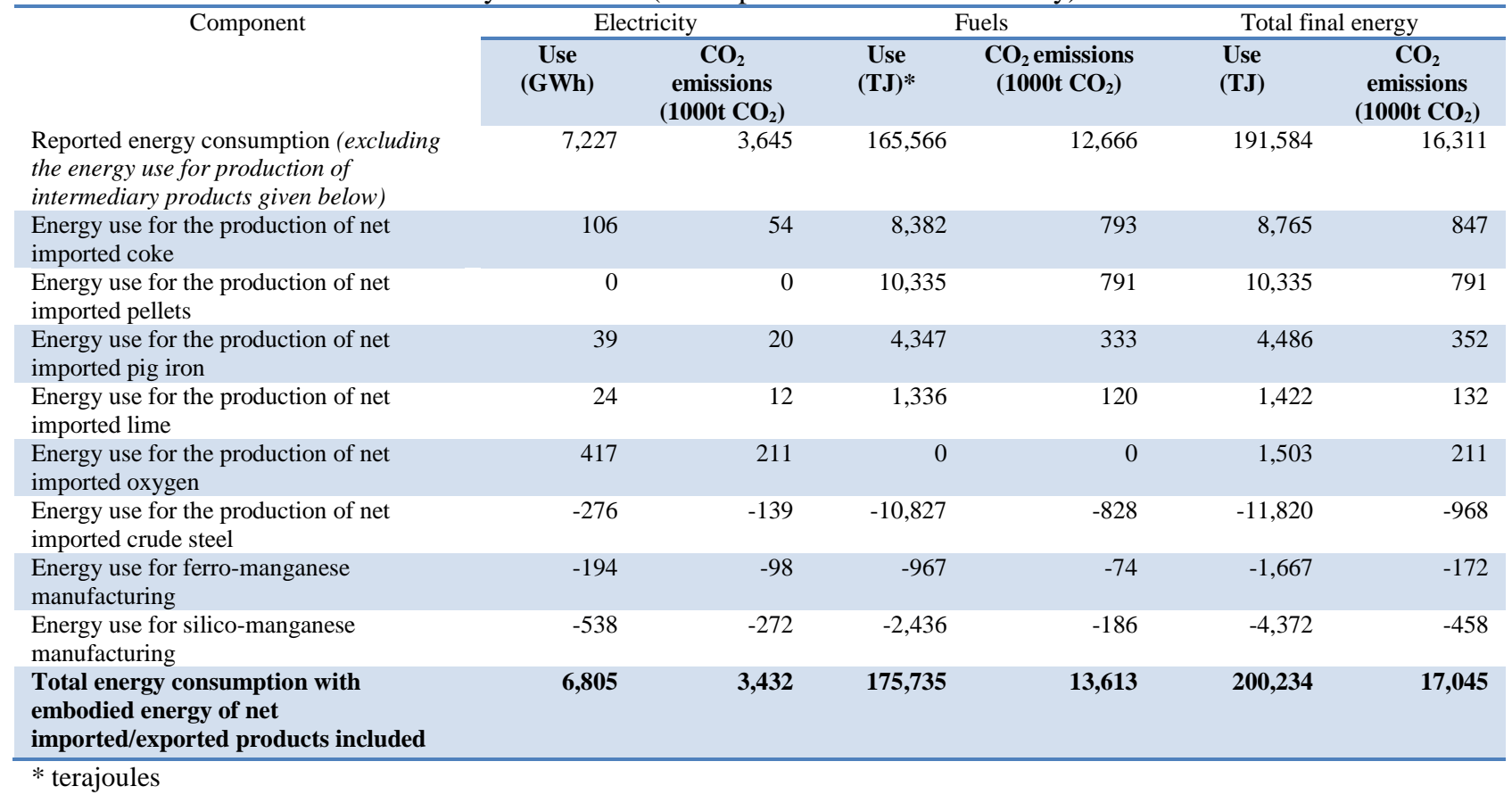

Table 11. Total energy consumption and $\mathrm{CO}_{2}$ emissions of U.S. steel industry production in 2010 based on study boundaries (net import is to the steel industry)

\begin{tabular}{|c|c|c|c|c|c|c|}
\hline \multirow[t]{2}{*}{ Component } & \multicolumn{2}{|c|}{ Electricity } & \multicolumn{2}{|c|}{ Fuel } & \multicolumn{2}{|c|}{ Total Final Energy } \\
\hline & $\begin{array}{c}\text { Use } \\
(\mathbf{G W h})\end{array}$ & $\begin{array}{c}\mathrm{CO}_{2} \\
\text { Emissions } \\
\left(1,000 t \mathrm{CO}_{2}\right)\end{array}$ & $\begin{array}{l}\text { Use } \\
(\mathbf{T J})^{*}\end{array}$ & $\begin{array}{c}\mathrm{CO}_{2} \\
\text { Emissions } \\
\left(1,000 t \mathrm{CO}_{2}\right)\end{array}$ & Use (TJ) & $\begin{array}{c}\mathrm{CO}_{2} \text { Emissions } \\
\left(1,000 t \mathrm{CO}_{2}\right)\end{array}$ \\
\hline $\begin{array}{l}\text { Energy use reported for the iron and } \\
\text { steel industry in EIA (excluding the } \\
\text { energy use for production of } \\
\text { intermediary products given below) }\end{array}$ & 50,360 & 29,161 & 941,110 & 91,246 & $1,122,406$ & 120,406 \\
\hline $\begin{array}{l}\text { Energy used for the production of net } \\
\text { imported oxygen }\end{array}$ & 4,131 & 2,392 & 0 & 0 & 14,872 & 2,392 \\
\hline $\begin{array}{l}\text { Energy used for the production of net } \\
\text { imported pig iron }\end{array}$ & 686 & 397 & 28,417 & 2,755 & 30,888 & 3,153 \\
\hline $\begin{array}{l}\text { Energy used for the production of net } \\
\text { imported DRI }\end{array}$ & 508 & 294 & 21,033 & 1,301 & 22,862 & 1,596 \\
\hline $\begin{array}{l}\text { Energy used for the rolling and finishing } \\
\text { of net imported ingots, blooms, billets, } \\
\text { and slabs }\end{array}$ & 5,270 & 3,052 & 7,385 & 469 & 26,357 & 3,520 \\
\hline $\begin{array}{l}\text { Embodied energy of net imported ingots, } \\
\text { blooms, billets, and slabs }\end{array}$ & 3,968 & 2,298 & 51,486 & 4,992 & 65,772 & 7,290 \\
\hline $\begin{array}{l}\text { Energy used for the production of net } \\
\text { imported coke }\end{array}$ & 662 & 383 & 19,269 & 1,823 & 21,651 & 2,206 \\
\hline $\begin{array}{l}\text { Energy used for the production of net } \\
\text { imported lime }\end{array}$ & 297 & 172 & 6,063 & 544 & 7,133 & 716 \\
\hline $\begin{array}{l}\text { Energy used for the production of net } \\
\text { imported pellets }\end{array}$ & 2,100 & 1,216 & 68,040 & 4,224 & 75,600 & 5,440 \\
\hline $\begin{array}{l}\text { Total energy consumption of steel } \\
\text { industry with embodied energy of net } \\
\text { imported/exported } \\
\text { auxiliary/intermediary products } \\
\text { included }\end{array}$ & 67,982 & 39,365 & $1,142,804$ & 107,353 & $1,387,541$ & 146,718 \\
\hline
\end{tabular}




\section{Results and discussion}

In this study, we use $\mathrm{CO}_{2}$ intensity as the index for comparison for the Chinese, German, Mexican, and U.S. iron and steel industries. We calculate the index of $\mathrm{CO}_{2}$ emissions per tonne of crude steel produced, based on the industry boundary definition described in Section 3.1 and shown in Figure 2.

$\mathrm{CO}_{2}$ intensity $=\frac{\mathrm{CO}_{2}}{\text { Crude steel production within the boundary }+ \text { Net trade of crude steel }}$

The $\mathrm{CO}_{2}$ intensity of steel production is influenced by a country's industry structure, technology, fuel choice, grid emissions factor, capacity utilization of steel plants, and materials (e.g., availability of scrap steel). We isolated the effects of some of these variables in factor analyses, two of which are presented in Section 4.1.

Figure 3 shows the $\mathrm{CO}_{2}$ intensities for the iron and steel industry in China, Germany, Mexico, and the U.S. in the year 2010. Crude steel production in the U.S. in 2010 was 80.5 Mt. In addition, there were $3.99 \mathrm{Mt}$ of net imported ingots, blooms, billets, and slabs. Thus, the total U.S. crude steel production used for the 2010 energy-intensity calculations was 84.49 Mt. Under the base-case analysis, as shown in Table 11 above, the $\mathrm{CO}_{2}$ emissions associated with the total electricity and fuel consumption in the U.S. iron and steel industry in 2010, based on the industry boundary defined in Section 3.1, were 39,365 and 107,353 thousand t $\mathrm{CO}_{2}$, respectively. If these emissions are divided by the production of crude steel given above, the $\mathrm{CO}_{2}$ intensities related to the electricity and fuel use can be calculated separately. The sum of these two $\mathrm{CO}_{2}$ intensities is given as the total $\mathrm{CO}_{2}$ intensity of the U.S. steel industry. Figure 3 shows the results of the same calculation of $\mathrm{CO}_{2}$ intensities for the steel industry in the other three countries studied.

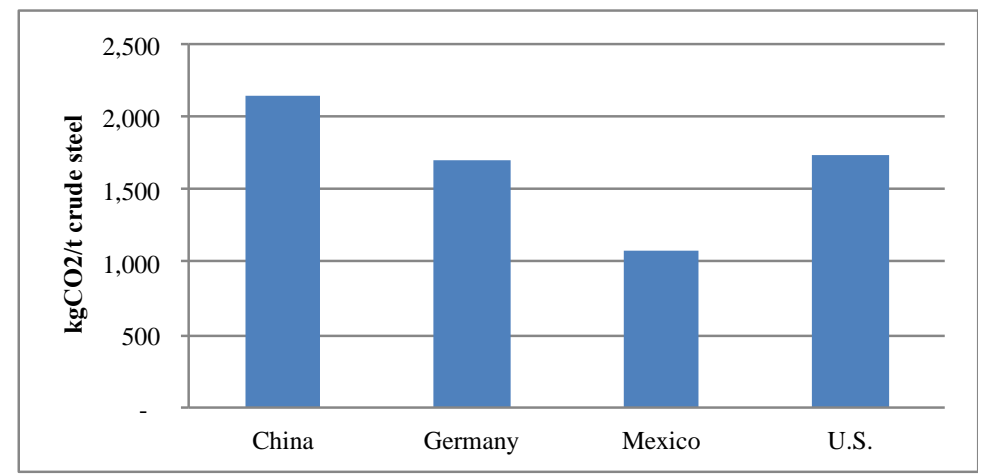

Figure 3. Base case - $\mathrm{CO}_{2}$ intensity of the iron and steel industry in China, Germany, Mexico, and the U.S. in 2010

As can be seen from Figure 3, China has the highest and Mexico has the lowest total steel industry $\mathrm{CO}_{2}$ intensity. The total $\mathrm{CO}_{2}$ intensity of the Chinese steel industry is almost twice that of the Mexican steel industry. Two main reasons for low total $\mathrm{CO}_{2}$ intensity in Mexico's steel industry are: 1) Mexico has the largest share of EAF steel production among the four countries studied (69.4\% in 2010), and 2) Mexico's steel industry consumes a larger share of natural gas compared to that in other countries studied. This results in a lower average emissions factor for fuels in Mexico. Another interesting point to note is that the total $\mathrm{CO}_{2}$ intensity of the German 
steel industry is $2 \%$ lower than that of the U.S. which is remarkable given that, in 2010, Germany had a lower share of EAF steel production (30.2\% of total production) than the U.S. (61.3\% of total production). EAF steel production has a much lower $\mathrm{CO}_{2}$ intensity than $\mathrm{BF} / \mathrm{BOF}$ steel production. Other factors influencing the $\mathrm{CO}_{2}$ intensities in the four countries' steel industries are discussed in Section 4.1.

In addition to calculating $\mathrm{CO}_{2}$ intensities for the entire steel industry, we calculated separately the $\mathrm{CO}_{2}$ intensities associated with the $\mathrm{EAF}$ and $\mathrm{BF} / \mathrm{BOF}$ production route in the four countries. Details about the calculation method for the energy intensities of EAF and BF/BOF production in China and the U.S. can be found in Hasanbeigi et al. (2011) and for Germany and Mexico in Appendices 1 and 2 of this paper. Figure 4 shows the $\mathrm{CO}_{2}$ intensities calculated for EAF and $\mathrm{BF} / \mathrm{BOF}$ production in China, Germany, Mexico, and the U.S.

One of the main reasons that $\mathrm{CO}_{2}$ intensity of EAF steel production in China is significantly higher than that in Germany and the U.S. is that more than $45 \%$ of the feed to EAFs in China in 2010 was pig iron (EBCISIY 2011). Pig iron is highly fuel and $\mathrm{CO}_{2}$ intensive. In the U.S., only about $10 \%$ of the feed to EAFs is pig iron and in Germany the share of pig iron feed is minimal. As mentioned above, the prevalence of natural gas as a fuel for Mexico's EAFs is one reason that the $\mathrm{CO}_{2}$ intensity of Mexico's EAFs is lowest (even marginally lower than Germany's); $98 \%$ of fossil fuel used in Mexico's EAF plants is natural gas, which has a lower emissions factor compared to that of coal and the other fossil fuels used in other countries. Other reasons are the relatively younger age and higher energy efficiency of Mexico's EAFs. The share of natural gas use in EAF plants is Germany is smaller than the share in Mexico. Mexico also has the lowest grid emissions factor, which helps to further reduce the $\mathrm{CO}_{2}$ intensity of Mexico's EAFs.

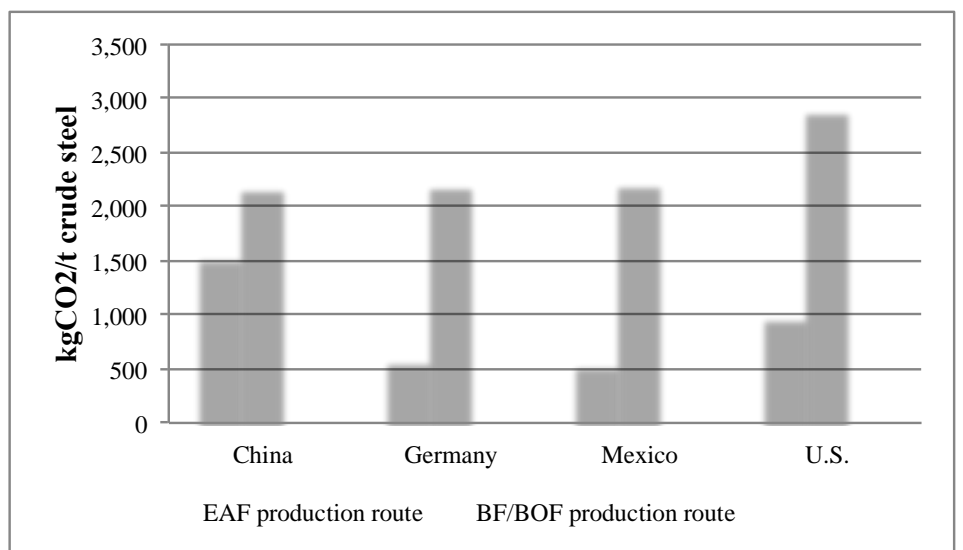

Figure 4. $\mathrm{CO}_{2}$ intensities for EAF and $\mathrm{BF} / \mathrm{BOF}$ production in China, Germany, Mexico, and the U.S. in 2010

Another noticeable result shown in Figure 4 is that the $\mathrm{CO}_{2}$ emissions intensities of $\mathrm{BF} / \mathrm{BOF}$ production route are quite similar in China, Germany and Mexico, but significantly higher in the U.S. The higher $\mathrm{CO}_{2}$ emissions intensity of BOF/BOF route in the U.S. could be because of various reasons such as older $\mathrm{BF} / \mathrm{BOF}$ plants and lower penetration of some major energy efficiency technologies such as coke dry quenching (CDQ) and top-pressure recovery turbine (TRT) in blast furnaces. However, detailed investigation of why BF/BOF steel production in the U.S. has significantly higher $\mathrm{CO}_{2}$ emissions intensity can be the topic of future studies. 
The intensities reported here are for the complete $\mathrm{BF} / \mathrm{BOF}$ and $\mathrm{EAF}$ production routes, which includes casting, rolling, and finishing. That is, these intensity values for BF/BOF and EAF production include the energy use of net imported fuel and auxiliary and intermediary products, as discussed above and within the industry boundary defined for this study (Figure 2). Also, the $\mathrm{CO}_{2}$ emissions intensities shown in Figures 3 and 4 might be different from $\mathrm{CO}_{2}$ emissions intensities calculated in other studies for the steel industry in the four countries studied here. The primary reason for this difference could be the differences in the definition of what is included within the industry boundary and therefore what is or is not included in the calculation of intensity values. For example, if another study does not include the embodied energy of imported fuel and auxiliary/intermediary products, then the $\mathrm{CO}_{2}$ intensity calculated in that study would likely be lower than the value calculated in this paper.

\subsection{Factor analyses}

In addition to the base case presented above, we analyzed the impact of several different factors on the iron and steel production $\mathrm{CO}_{2}$ intensity value for each country. The purpose of these factor analyses was to determine which variables are most important for explaining $\mathrm{CO}_{2}$ intensity differences among China, Germany, Mexico, and the U.S.

The first factor analysis examines the impact on $\mathrm{CO}_{2}$ intensity of a change in EAF ratio. This analysis has two sub-sections:

- 1.a. uses the country-specific fuel conversion factors, country-specific electricity grid $\mathrm{CO}_{2}$ emissions factors, worldsteel conversion factors for auxiliary/intermediary products, and China's EAF ratio in 2010 to calculate $\mathrm{CO}_{2}$ intensities for Germany, Mexico, and the U.S.

- 1.b. uses the country-specific fuel conversion factors, country-specific electricity grid $\mathrm{CO}_{2}$ emissions factors, worldsteel conversion factors for auxiliary/intermediary products, and the U.S. EAF ratio in 2010 to calculate $\mathrm{CO}_{2}$ intensities for China, Germany, and Mexico.

The second factor analysis examines the impact on $\mathrm{CO}_{2}$ intensity of a change in electricity grid $\mathrm{CO}_{2}$ emissions factors. It has two sub-sections as follows:

- 2.a. uses the country-specific fuel conversion factors, worldsteel conversion factors for auxiliary/intermediary products, and China's electricity grid $\mathrm{CO}_{2}$ emissions factor in 2010 to calculate a $\mathrm{CO}_{2}$ intensities for Germany, Mexico, and the U.S.

- 2.b. uses the country-specific fuel conversion factors, worldsteel conversion factors for auxiliary/intermediary products, and the $\underline{U . S}$. electricity grid $\mathrm{CO}_{2}$ _emissions factor in 2010 to calculate $\mathrm{CO}_{2}$ intensities for China, Germany, and Mexico. 
Table 12 and Figure 5 show the results for the factor analyses of the four countries studied. This comparison presents the results of the base case and the two factor analyses, with the $\mathrm{CO}_{2}$ intensities calculated for China, Germany, Mexico, and the U.S.

Table 12. Energy-related $\mathrm{CO}_{2}$ intensities for the iron and steel industry in China, Germany, Mexico, and the U.S. (2010)

\begin{tabular}{|c|c|c|c|}
\hline No. & Scenarios & Country & $\begin{array}{c}\text { Total energy- } \\
\text { related } \mathrm{CO}_{2} \\
\text { intensity } \\
\left(\mathrm{kgCO}_{2} / \mathrm{t} \text { crude steel }\right)\end{array}$ \\
\hline \multirow{4}{*}{ Base } & Country-specific NCVs for fuels & U.S. & 1,736 \\
\hline & Country-specific electricity $\mathrm{CO}_{2}$ emissions factor & China & 2,148 \\
\hline & worldsteel conversion factors aux/intermediary products & Germany & 1,708 \\
\hline & & Mexico & 1,080 \\
\hline \multirow{15}{*}{ 1a } & Country-specific NCVs for fuels & & \\
\hline & Country-specific electricity $\mathrm{CO}_{2}$ emissions factor & U.S. & 2,703 \\
\hline & worldsteel conversion factors aux/intermediary products & & \\
\hline & (Base Scenario) & & \\
\hline & (Base Scenario) & & \\
\hline & Country-specific NCVs for fuels & China & 2,148 \\
\hline & $\begin{array}{l}\text { Country-specific electricity } \mathrm{CO}_{2} \text { emissions factor } \\
\text { worldsteel conversion factors aux/intermediary products }\end{array}$ & & \\
\hline & Country-specific NCVs for fuels & & \\
\hline & Country-specific electricity $\mathrm{CO}_{2}$ emissions factor & Germany & 2,036 \\
\hline & worldsteel conversion factors aux/intermediary products & & \\
\hline & China 2010 EAF ratio used for Germany & & \\
\hline & Country-specific NCVs for fuels & & \\
\hline & Country-specific electricity $\mathrm{CO}_{2}$ emissions factor & Mexico & 2,074 \\
\hline & worldsteel conversion factors aux/intermediary products & & \\
\hline & China 2010 EAF ratio used for Mexico & & \\
\hline \multirow{16}{*}{ 1b } & (Base Scenario) & \multirow{4}{*}{ U.S. } & \multirow{4}{*}{1,736} \\
\hline & Country-specific NCVs for fuels & & \\
\hline & Country-specific electricity $\mathrm{CO}_{2}$ emissions factor & & \\
\hline & worldsteel conversion factors aux/intermediary products & & \\
\hline & Country-specific NCVs for fuels & \multirow{4}{*}{ China } & \multirow{4}{*}{1,783} \\
\hline & Country-specific electricity $\mathrm{CO}_{2}$ emissions factor & & \\
\hline & worldsteel conversion factors aux/intermediary products & & \\
\hline & U.S. 2010 EAF ratio used for China & & \\
\hline & Country-specific NCVs for fuels & \multirow{4}{*}{ Germany } & \multirow{4}{*}{1,200} \\
\hline & Country-specific electricity $\mathrm{CO}_{2}$ conversion factors & & \\
\hline & worldsteel conversion factors aux/intermediary products & & \\
\hline & US 2010 EAF ratio used for Germany & & \\
\hline & Country-specific NCVs for fuels & \multirow{4}{*}{ Mexico } & \multirow{4}{*}{1,220} \\
\hline & Country-specific electricity $\mathrm{CO}_{2}$ conversion factors & & \\
\hline & worldsteel conversion factors aux/intermediary products & & \\
\hline & US 2010 EAF ratio used for Mexico & & \\
\hline \multirow{3}{*}{$2 \mathbf{a}$} & Country-specific NCVs for fuels & \multirow{3}{*}{ U.S. } & \multirow{3}{*}{1,911} \\
\hline & worldsteel conversion factors aux/intermediary products & & \\
\hline & $\begin{array}{l}\text { China electricity } \mathrm{CO}_{2} \text { emissions factor used for U.S. } \mathrm{CO}_{2} \\
\text { intensity calculation }\end{array}$ & & \\
\hline
\end{tabular}




\begin{tabular}{|c|c|c|c|}
\hline No. & Scenarios & Country & $\begin{array}{c}\text { Total energy- } \\
\text { related } \mathrm{CO}_{2} \\
\text { intensity } \\
\left(\mathrm{kgCO}_{2} / \mathrm{t} \text { crude steel) }\right.\end{array}$ \\
\hline & $\begin{array}{l}\text { (Base Scenario) } \\
\text { Country-specific NCVs for fuels } \\
\text { Country-specific electricity } \mathrm{CO}_{2} \text { emissions factor } \\
\text { worldsteel conversion factors aux/intermediary products }\end{array}$ & China & 2,148 \\
\hline & $\begin{array}{l}\text { Country-specific } \mathrm{NCV} \text { s for fuels } \\
\text { worldsteel conversion factors aux/intermediary products } \\
\text { China electricity } \mathrm{CO}_{2} \text { emissions factor used for Germany } \\
\mathrm{CO}_{2} \text { intensity calculation }\end{array}$ & Germany & 1,798 \\
\hline & $\begin{array}{l}\text { Country-specific NCVs for fuels } \\
\text { worldsteel conversion factors aux/intermediary products } \\
\text { China electricity } \mathrm{CO}_{2} \text { emissions factor used for Mexico } \mathrm{CO}_{2} \\
\text { intensity calculation }\end{array}$ & Mexico & 1,197 \\
\hline \multirow{4}{*}{$2 b$} & $\begin{array}{l}\text { (Base Scenario) } \\
\text { Country-specific NCVs for fuels } \\
\text { Country-specific electricity } \mathrm{CO}_{2} \text { emissions factor } \\
\text { worldsteel conversion factors aux/intermediary products }\end{array}$ & U.S. & 1,736 \\
\hline & $\begin{array}{l}\text { Country-specific NCVs for fuels } \\
\text { worldsteel conversion factors aux/intermediary products } \\
\text { US electricity } \mathrm{CO}_{2} \text { emissions factor used for } \mathrm{China}^{\mathrm{CO}_{2}} \\
\text { intensity calculation }\end{array}$ & China & 2,052 \\
\hline & $\begin{array}{l}\text { Country-specific fuel conversion factors } \\
\text { worldsteel conversion factors aux/intermediary products } \\
\mathrm{US} \text { electricity } \mathrm{CO}_{2} \text { emissions factor used for Germany } \mathrm{CO}_{2} \\
\text { intensity calculation }\end{array}$ & Germany & 1,720 \\
\hline & $\begin{array}{l}\text { Country-specific fuel conversion factors } \\
\text { worldsteel conversion factors aux/intermediary products } \\
\mathrm{US} \text { electricity } \mathrm{CO}_{2} \text { emissions factor used for Mexico } \mathrm{CO}_{2} \\
\text { intensity calculation }\end{array}$ & Mexico & 1,102 \\
\hline
\end{tabular}

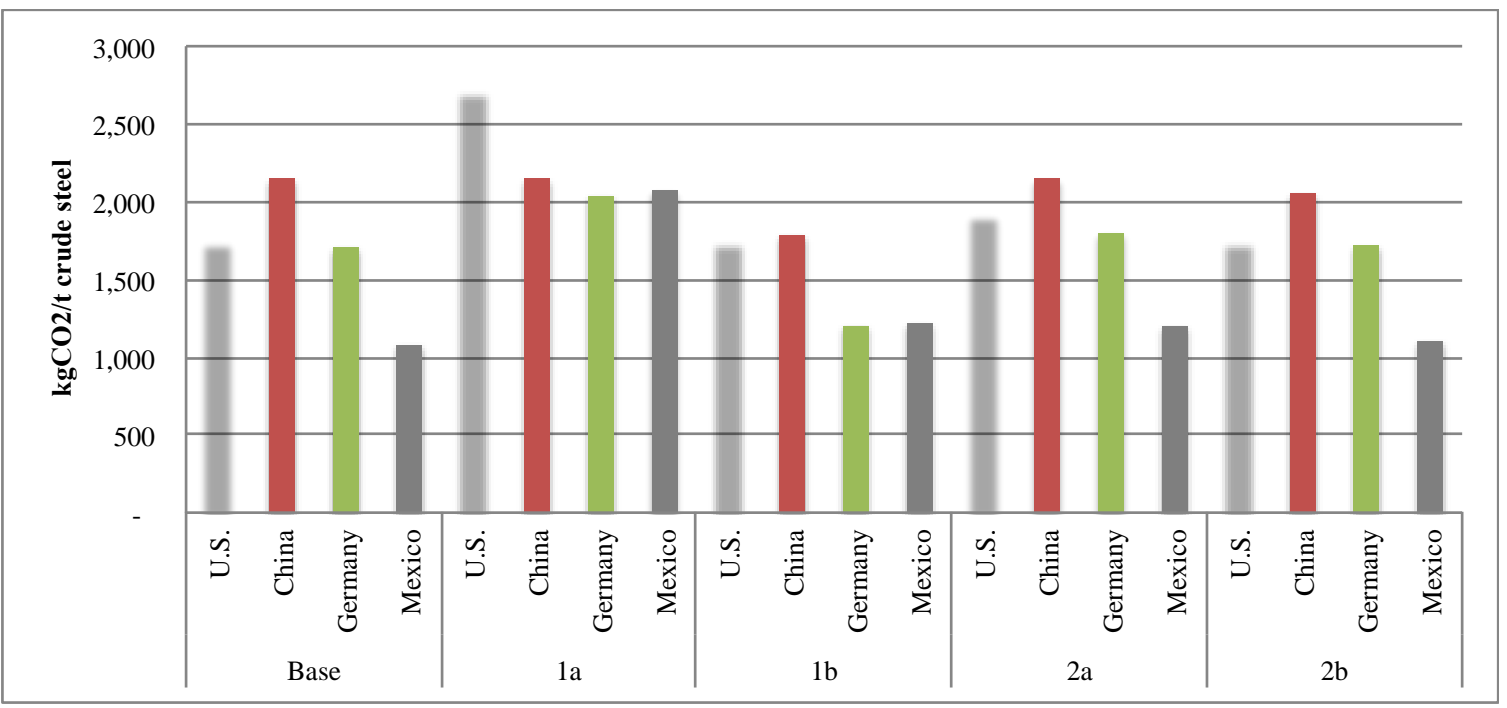

Figure 5. Comparison of $\mathrm{CO}_{2}$ intensities for the iron and steel industry in China, Germany, Mexico, and the U.S.: Base case and four factor analysis results (2010) 
Factor analysis 1a shows that when China's 2010 EAF ratio (which is the lowest of the EAF ratios among the countries studied) is used for $\mathrm{CO}_{2}$ intensity calculations for the other three countries, the total $\mathrm{CO}_{2}$ intensities of the German, Mexican, and U.S. steel industries increase by $19 \%, 92 \%$, and $56 \%$, respectively, compared to their base case analyses. The reason that the change in the $\mathrm{CO}_{2}$ intensity is larger for Mexico than for Germany is the larger gap between the EAF ratio in Mexico in 2010 (69.4\%) that was used for the base case analysis, and the EAF ratio in China in 2010 (9.8\%) that is used for the calculation in factor analysis 1a. In this regard, the EAF ratio in Germany in 2010 (31.2\%) is closer to China's EAF ratio.

The results of factor analyses $1 \mathrm{a}$ and $1 \mathrm{~b}$ illustrate the strong impact of the EAF ratio on the $\mathrm{CO}_{2}$ intensity of steel production in the countries studied. Therefore, in all industry-level comparison studies, this factor should always be taken into account and its effect evaluated.

Factor analysis 2a shows that when China's electricity grid $\mathrm{CO}_{2}$ emissions factor in 2010 (which is the highest among those of the countries studied) is used for $\mathrm{CO}_{2}$ intensity calculations in the other three countries, the total $\mathrm{CO}_{2}$ intensities of the German, Mexican, and U.S. steel industries increase by $5 \%, 11 \%$, and $10 \%$, respectively, compared to their base case analyses. In the base case analysis, the $\mathrm{CO}_{2}$ intensities associated with electricity use accounted for $11 \%$ and $27 \%$ of the total $\mathrm{CO}_{2}$ intensity of the German and U.S. steel industries in 2010, respectively. This is also mainly because of a higher percentage of EAF steel production in the U.S. compared to that in Germany. Therefore, the increase in the $\mathrm{CO}_{2}$ intensity as a result of rise in electricity grid $\mathrm{CO}_{2}$ emissions factor is smaller for Germany and larger for the U.S. in this factor analysis.

On the other hand, factor analysis $2 \mathrm{~b}$ shows that when U.S. electricity grid $\mathrm{CO}_{2}$ emissions factor in 2010 is used for $\mathrm{CO}_{2}$ intensity calculations in the other three countries, the total $\mathrm{CO}_{2}$ intensities of the German and Mexican steel industries increase by $1 \%$ and $2 \%$, respectively and in China decreased by $4 \%$ compared to their base case analyses. This is because electricity grid $\mathrm{CO}_{2}$ emissions factor in Germany and Mexico is lower and in China is higher than that in the U.S.

Several uncertainties can influence the results and their interpretation. These include the calculation for the deduction of energy use for ferro-alloys from Chinese statistics (ferro-alloys are not within the boundary of this study, and how we addressed ferro-alloy energy use in the other three countries varies). For detailed discussion of the uncertainties for China and the U.S., please see Hasanbeigi et al. (2011). The uncertainties related to the calculation of $\mathrm{CO}_{2}$ intensities for the steel industry in Germany and Mexico are discussed in Appendices 1 and 2 of this paper.

\subsection{Explanatory variables}

As noted earlier, the purpose of the analysis presented in this paper is to test a methodology for quantifying and comparing the $\mathrm{CO}_{2}$ intensities of steel production in China, Germany, Mexico, and the U.S., using defined boundaries and conversion factors. There are also other variables that might explain why the steel industry's $\mathrm{CO}_{2}$ intensity values differ among the four countries, but we have not discussed them in details because of lack of space in this paper:

1) The share of EAF steel in total steel production. Higher share of EAF helps to reduce $\mathrm{CO}_{2}$ intensity of the steel industry. 
2) The age of steel manufacturing facilities in each country. Newer plants often have lower $\mathrm{CO}_{2}$ intensity compared to older plants.

3) The fuel shares in the iron and steel industry in each country. The use of lower carbon fuels in the steel industry (e.g. natural gas instead of coal) helps to lower the $\mathrm{CO}_{2}$ intensity of the steel industry

4) The steel product mix in each country. Some steel products need less finishing process, which help to reduce $\mathrm{CO}_{2}$ intensity of the steel product.

5) The level of penetration of energy-efficient technologies. Higher level of penetration of energy efficiency technologies help to reduce $\mathrm{CO}_{2}$ intensity of the industry.

6) Capacity utilization of plants. Higher capacity utilization improves overall energy performance compared to lower capacity utilization if all other factors remain constant.

7) Cost of energy and raw materials. Low-cost energy and raw materials are key components of managing costs in the steel industry. Changing energy and materials sources in order to optimize costs can affect the $\mathrm{CO}_{2}$ and energy intensities of a plant.

8) Differing environmental requirements from country to country. Environmental regulations affect industry $\mathrm{CO}_{2}$ intensity. Operation of pollution control equipment requires energy, which adds $\mathrm{CO}_{2}$ emissions.

\section{Conclusions}

The goal of this study was to develop a methodology for accurately comparing the energy-related $\mathrm{CO}_{2}$ emissions intensity of steel production in different countries. We applied the methodology to an analysis of energy and emissions intensity of the steel industry in China, Germany, Mexico, and the U.S. A key finding of this study is that the methodology must clearly define the industry boundaries (what materials and activities are and are not included) and the energy and $\mathrm{CO}_{2}$ conversion factors used in the analysis because both elements have significant impact on the results. The boundary definition must address how to account for imported and exported inputs and intermediate products. Another key finding is that it is not possible to accurately compare the $\mathrm{CO}_{2}$ intensity of steel production in different countries without performing multiple factor analyses. No single factor analysis can best compare all countries; each factor analysis highlights different issues affecting the accuracy and fairness of the comparisons. For example, for this comparison of the four countries studied, the results change significantly when the differences in production structure (i.e., the percentage of EAFs in each country) are taken into account in comparing the $\mathrm{CO}_{2}$ intensity values.

This analysis shows that the structure of the steel industry heavily influences the $\mathrm{CO}_{2}$ intensity and that if the German, Mexican, and U.S. steel industries were similar in structure to the Chinese steel industry (i.e., with the same EAF ratio - scenario 1a in our analysis), the $\mathrm{CO}_{2}$ emissions intensity of steel production in Germany, Mexico, and the U.S. would increase by $19 \%$, $92 \%$, and $56 \%$, respectively compared to their actual values (base case scenario). Another important factor is the national average grid electricity $\mathrm{CO}_{2}$ emissions. Scenario $2 \mathrm{a}$ showed that if China's national average grid electricity $\mathrm{CO}_{2}$ emissions factor was used for Germany, Mexico, 
and the U.S., the $\mathrm{CO}_{2}$ emissions intensity of steel production in those three countries would increase by $5 \%, 11 \%$, and $10 \%$, respectively, compared to their actual values.

These examples demonstrate that it is important to perform multiple factor analyses to accurately identify the reasons for differences among calculated country-level $\mathrm{CO}_{2}$ intensities. Only after the underlying reasons are understood can accurate comparisons be made among countries. Additional potentially important factors relevant to the industry and countries in this study could not be quantitatively analyzed because of scope limitations. Those were presented as explanatory variables in this paper.

In the context of national carbon inventory and Intergovernmental Panel on Climate Change (IPCC), the points highlighted in this paper should be taken into account when calculating, analyzing, and comparing the $\mathrm{CO}_{2}$ emissions intensity of steel production in different countries. For example, as shown above, comparing the total $\mathrm{CO}_{2}$ emissions intensity of steel production in a country can be misleading and less informative. Instead, $\mathrm{CO}_{2}$ emissions intensity of steel production by process type $(\mathrm{BE} / \mathrm{BOF}$ and $\mathrm{EAF})$ should be calculated and compared across countries.

\section{Acknowledgments}

This work was supported by the Energy Foundation China through the U.S. Department of Energy under Contract No. DE-AC02-05CH11231. The authors gratefully acknowledge the significant contribution of Nathaniel Aden, a former staff member at Lawrence Berkeley National Laboratory, and Zhang Chunxia, Li Xiuping, and Shangguan Fangqin from State Key Laboratory of Advanced Steel Processes and Products, China Iron \& Steel Research Institute (CISRI), Beijing, China in Phase I of this project. We are also grateful to Zhang Chunxia of CISRI, Hans Bodo Lüngen of Steel Institute VDEh of Germany, Brett Smith of AISI, Claudia Sheinbaum Pardo of National Autonomous University of Mexico, and Nihan Karali of LBNL for their comments on and inputs to this paper.

\section{References}

AG Energiebilanzen. 2013. www.ag-energiebilanzen.de (in German).

Aichinger, H.M., Steffen, R. 2006.Maßnahmen zur $\mathrm{CO}_{2}$-Minderung bei der Stahlerzeugung. Chemie Ingenieur Technik 78 (4): 397-406. (in German).

Andersen, J.P., Hyman B. 2001. "Energy and material flow models for the US steel industry." Energy 26(2) (February): 137-159.

Arens, M., Worrell, E., Schleich, J. 2012.“Energy intensity development of the German iron and steel industry between 1991 and 2007”. Energy 45:786e797.

Association for Iron and Steel Technology (AIST). 2010a. 2010 North American BOF Roundup. Iron \& Steel Technology. November.

AIST. 2010b. 2010 EAF Roundup. Iron \& Steel Technology. February.

AIST. 2008. Directory of Iron and Steel Plants. Warrendale PA: AIST. 
China Metallurgical Industry Planning and Research Institute (MIPRI). 2012. "Eleventh FiveYear Plan" Steelmaking Technology Advances Review and Outlook (in Chinese). Available at http://www.steelplanning.cn/zyzxfw/ylyl/hyfx/lg/201211/t20121129_1057.html

Chinese society for metals (CSM). 2012-2013. Report on Advances in Metallurgical Engineering and Technology. Beijing, China. (in Chinese)

Chukwuleke, O.P. Cai, J.J. Chukwujekwu , S. Xiao, S. 2009. "Shift From Coke to Coal Using Direct Reduction Method and Challenges." Journal of Iron and Steel Research International 16(2): 01-05.

Comision Reguladora de Energia (CRE). 2014. Electricity generation and import permissions as of July $31^{\text {st }}$ 2014. http://www.cre.gob.mx/documento/1814.xlsx_(in Spanish)

Editorial Board of China Iron and Steel Industry Yearbook (EBCISIY). 2011. China Iron and Steel Industry Yearbook. Beijing, China (in Chinese).

EBCISIY. 2008. China Iron and Steel Industry Yearbook. Beijing, China (in Chinese).

Energy Conservation and Emissions Reduction Task Force of China Iron and Steel Industry Association (ECERTF). 2008. "Directions and Measures of Energy Conservation and Emission Reduction in China's Iron and Steel Industry”. China Iron and Steel Industry, 2008, (10): 39-44 (in Chinese)

Farla, J., Blok, M. 2001. "The quality of energy intensity indicators for international comparison in the iron and steel industry." Energy Policy Volume 29, Issue 7, June 2001, Pages 523-543.

Hasanbeigi, A., Price, L., Aden, N., Zhang C., Li X., Shangguan F. 2011. A Comparison of Iron and Steel Production Energy Use and Energy Intensity in China and the U.S. Berkeley CA: Lawrence Berkeley National Laboratory Report LBNL-4836E.

Haque N., Norgate T. 2013. "Estimation of Greenhouse Gas Emissions from Ferroalloy Production Using Life Cycle Assessment with Particular Reference to Australia." Journal of Cleaner Production 39: 220-30.

Instituto Nacional de Estadistica y Geografía (INEGI). 2012. La industria Sidergúrgica en México. (in Spanish).

Intergovernmental Panel on Climate Change (IPCC). 2006. 2006 IPCC Guidelines for National Greenhouse Gas Inventories; Reference Manual (Volume 2. Energy), pp. 2-16. Retrieved on November 21, 2008 from: http://www.ipcc-nggip.iges.or.jp/public/2006gl/vol2.html

Kim, Y., Worrell, E. 2002. "International comparison of $\mathrm{CO}_{2}$ emission trends in the iron and steel industry." Energy Policy 30 (10) (August): 827-838.

Kirschen M., Badr K., Pfeifer H. 2011. "Influence of direct reduced iron on the energy balance of the electric arc furnace in steel industry". Energy 36: 6146-6155.

Ministry of Industry and Information Technology (MIIT), 2015. Surpassing the 2014 phasing out targets. http://www.gov.cn/xinwen/2015-02/02/content_2813195.htm

MIIT, 2014. Status of completing 2013 phasing out targets. http://www.miit.gov.cn/n11293472/n11293832/n11293907/n16316572/16322104.html

MIIT. 2013. Status of completing 2012 phasing out targets. 
http://www.nea.gov.cn/2013-12/09/c_132953315.htm

MIIT. 2010. Phasing Out Backward Capacities for 11th five year plan (in Chinese).

National Bureau of Statistics (NBS). 2011. China Energy Statistics Yearbook 2011. Beijing:

China Statistics Press.

Plantfacts. 2013. Blast Furnaces. VDEh database. Stahlinstitut VDEh. (in German ).

Ruth M., Amato, A., Davidsdottir, B. 2000. "Impacts of Market-based Climate Change Policy on the US Iron and Steel Industry." Energy Sources 22 (3): 269 - 280.

Secretaría de Economía (SE). 2012. Mexican Mining Statistical Yearbook 2012.

Secretaría de Energía (SENER). 2012. National Energy Balance of 2012. (in Spanish).

SENER. 2014. Prospectiva del Sector Eléctrico 2013-2027. (in Spanish) .

Shangguan F.Q., Li X.P., and Zhang C.X. 2009. "Main Energy-Saving Measures in Iron and Steel Production and Analysis on Their CO2 Emission Reduction Potentials". Metallurgical Energy, 2009, 28(1): 3-7 (in Chinese)

Stahlinstitut VDEh. 2010. $\mathrm{CO}_{2}$-Monitoring-Fortschrittsbericht der Stahlindustrie in Deutschland. Berichtsjahr 2010. Düsseldorf, Germany. (in German).

Stubbles J. 2000. Energy Use in the U.S. Steel Industry: A Historical Perspective and Future Opportunities. U.S. Department of Energy, Office of Industrial Technologies, Washington, DC.

Tanaka, K. 2008. "Assessment of energy efficiency performance measures in industry and their application for policy.” Energy Policy 36: 2887-2902.

Tornell A. 1997. Rational Atrophy: The US Steel Industry. Working Paper 6084. Cambridge: National Bureau of Economic Research.

Umweltbundesamt (UBA), Deutsche Emissionshandelsstelle (DEHSt). 2012a. Einheitliche Stoffwerte für Emissionsfaktoren, Heizwerte und Kohlenstoffgehalte für Brennstoffe, Rohstoffe und Produkte. (in German).

Umweltbundesamt (UBA). 2012b. Entwicklung der spezifischen Kohlendioxid-Emissionen des deutschen Strommix 1990-2010 und erste Schätzungen 2011. (in German).

U.S. Department of Energy, Energy Information Administration (U.S. DOE/EIA). 2013a. Manufacturing Energy Consumption Survey (MECS)-2010 data (Table 1.2). Washington, DC: EIA. http://www.eia.doe.gov/emeu/mecs/mecs2006/2006tables.html

U.S. DOE/EIA. 2013b. Manufacturing Energy Consumption Survey (MECS)-2006 data (Table 8.3). Washington, DC: EIA. http://www.eia.doe.gov/emeu/mecs/mecs2006/2006tables.html

U.S. DOE/EIA. 2013c. Manufacturing Energy Consumption Survey (MECS)-2006 data (Table 8.2). Washington, DC: EIA. http://www.eia.doe.gov/emeu/mecs/mecs2006/2006tables.html

U.S. DOE/EIA. 2013d. Manufacturing Energy Consumption Survey (MECS)-2002 data (Table 8.1). Washington, DC: EIA. http://www.eia.doe.gov/emeu/mecs/mecs2006/2006tables.html

U.S. DOE/EIA. 2012. Electricity Data. (Tables on Generation by energy sources and Emissions). Washington, DC: EIA. http://www.eia.gov/electricity/data.cfm\#generation 
U.S. Geological Survey (USGS). 2011a. Minerals commodity Summaries.

http://minerals.usgs.gov/minerals/pubs/mcs/2011/mcs2011.pdf

USGS. 2011b. Minerals Yearbook- Iron and Steel 2010.

http://minerals.er.usgs.gov/minerals/pubs/commodity/iron_\&_steel/myb1-2006-feste.pdf

USGS. 2010a. Iron and Steel Mineral Commodity Summary.

http://minerals.usgs.gov/minerals/pubs/commodity/iron_\&_steel/mcs-2010-feste.pdf.

USGS. 2010b. Iron and Steel Statistics. http://minerals.usgs.gov/ds/2005/140/ironsteel.pdf

Wirtschaftsvereinigung (WV) Stahl, Stahlinstitut VDEh. 2013. Statistisches Jahrbuch der Stahlindustrie 2013/2014. Düsseldorf, Germany. (in German).

worldsteel. 2015. Steel Statistical Yearbook 2015. http://www.worldsteel.org/statistics/statisticsarchive/yearbook-archive.html

World Steel Association (worldsteel). 2013. Crude steel production, 1980-2012.

http://www.worldsteel.org/statistics/statistics-archive/annual-steel-archive.html

worldsteel. 2011. Steel Statistical Yearbook 2011. http://www.worldsteel.org/statistics/statisticsarchive/yearbook-archive.html

worldsteel. 2008a. Sustainability Report of the World Steel Industry.

worldsteel. 2008b. World Steel Sustainability Indicator Methodology.

http://www.worldsteel.org/pictures/storyfiles/SR08\%20mthodology.pdf

worldsteel. n.d. $\mathrm{CO}_{2}$ Emissions Data Collection - User Guide, Version 6,

http://www.worldsteel.org/climatechange/files/2/2/Data\%20collection\%20user\%20guide.pdf

Worrell E., Price L., Martin N., Farla J., Schaeffer R. 1997. "Energy intensity in the iron and steel industry: a comparison of physical and economic indicators," Energy Policy 25 (7) (June): 727-744.

Yin R. 2009. Metallurgical Process Engineering (Version 2). Beijing: Metallurgy Industry Press. (in Chinese) 


\title{
Appendices
}

\section{Appendix A. Data preparation and analysis for Germany's steel industry}

\begin{abstract}
A.1. Energy-use data in Germany
The analyses for the German steel industry are based on data from the German Federal Statistical Office, which publishes annual iron and steel statistics. Energy consumption is reported in physical units, i.e. tonne for solid fossil and liquid fuels as well as steam; cubic meters for gases and oxygen; and kilowatt-hours for electricity. The following energy carriers are reported: coke, coke breeze, hard coal, natural gas, coke oven gas, oxygen, liquid fuels, other gases, BF gas, $\mathrm{BOF}$ gas, electricity, and steam. To each energy carrier, we assign a specific heating value and a specific $\mathrm{CO}_{2}$ emissions factor. In the German steel statistics, all gases are reported as natural-gas equivalent, so the heating value used for all gases in the calculations is similar to that of natural gas. Coke ovens are not covered in the German iron and steel statistics, so in our calculation we treat coke and coke breeze as purchased energy carriers. Because steam and electricity are also produced in on-site facilities, we only treat net-imported steam and electricity as purchased energy carriers. Other purchased energy carriers include: pellets, sinter, direct reduced iron, pig iron and crude steel (i.e., ingots, blooms, billets, and slabs).
\end{abstract}

\section{A.2. Energy and carbon dioxide intensity for electric arc furnace and blast furnace/basic oxygen furnace production in Germany}

In German iron and steel statistics, energy consumption is not only reported by energy carriers but also by major industry processes. These processes include sinter and ore preparation, BF operations, EAF, BOF steelworks, rolling, on-site power plants, on-site steam generation, and other facilities. To calculate the $\mathrm{CO}_{2}$ intensity for EAF-steel and $\mathrm{BF} / \mathrm{BOF}$ steel, we assign a percentage of the processes to the two steel production processes (BF/BOF and EAF). Because all on-site power plants, sinter plants, BFs, and BOFs are located at integrated steel mills, their energy use and emissions are associated only with the BF/BOF production process. EAFs are assigned to the EAF steelmaking process. Steam-generation plants and other facilities are assigned to the $\mathrm{BF} / \mathrm{BOF}$ route with the portion of $94 \%$ and $75 \%$, respectively. The remainder is associated to EAF route. Energy use of rolling mills is allocated to BF/BOF and EAF process based on each production route's share of total crude steel production in Germany in 2010, i.e. $30.2 \%$ EAF steelmaking and $69.8 \% \mathrm{BF} / \mathrm{BOF}$ steelmaking.

\section{A.3. Uncertainties in the calculation of carbon dioxide intensities for the German steel industry}

Two uncertainties are associated with our calculation of the $\mathrm{CO}_{2}$ intensity of German iron and steel production:

1. The data for our calculations are based on energy consumption provided in physical units. For each energy carrier we assumed a certain heating value to calculate the $\mathrm{CO}_{2}$ intensity, and we used $\mathrm{CO}_{2}$ conversion factors expressed in $\mathrm{kg} \mathrm{CO}_{2} / \mathrm{GJ}$. The heating values for energy carriers can vary slightly across countries. For example, we assumed a countryspecific heating value of $29.3 \mathrm{GJ} / \mathrm{t}$ for coal in Germany, while the International Energy 
Agency (IEA) value is $28.2 \mathrm{GJ} / \mathrm{t}$. Hasanbeigi et al. (2011) found that differences in fuel heating values have minimal impact on the results.

2. Another uncertainty is in the allocation of some sub-processes to the EAF and BF/BOF steelmaking production process. We assumed the following shares for the EAF route: steam generation $6 \%$, rolling $31 \%$, other facilities $25 \%$. Although these assumptions pose some level of uncertainty in our analysis, we believe our detailed allocation of subprocesses to each production route makes our calculation of the $\mathrm{CO}_{2}$ intensity of the two steelmaking routes fairly accurate.

\section{Appendix B. Data preparation and analysis for Mexico's steel industry}

\section{B.1. Energy-use data in Mexico}

Energy consumption information for Mexico comes from energy balances (SENER 2012) and the Mexican energy regulatory commission (CRE 2014). It is important to mention that in Mexico, SENER reports the final energy consumption of the iron and steel industry as the energy used by the NAICS 3311 category "Iron and Steel Mills and Ferroalloy Manufacturing," with no further disaggregation (SENER 2012). Thus, to use the SENER statistics in our analysis, which excludes ferro-alloy manufacturing from the definition of the industry, we have to deduct the energy used to produce the ferro-alloys from the aggregate energy consumption reported by SENER. Because there are no previous studies or information about the energy use or intensity of ferro-alloy manufacturing in Mexico, we used final energy intensity values from a by Haque and Norgate (2013) along with data on the production of ferro-alloys (Table B.1).

\begin{tabular}{|c|c|c|}
\hline Fuel & $\begin{array}{c}\text { Ferro- } \\
\text { manganese } \\
\text { alloy }\end{array}$ & $\begin{array}{c}\text { Silico- } \\
\text { manganese } \\
\text { alloy }\end{array}$ \\
\hline Coke $(\mathrm{GJ} / \mathrm{t})$ & 8.37 & 15.09 \\
\hline Coal (GJ/t) & 3.57 & 3.02 \\
\hline Electricity $(\mathrm{GJ} / \mathrm{t})$ & 8.64 & 14.40 \\
\hline Total (GJ/t) & 20.58 & 32.51 \\
\hline Production $(\mathrm{Mt})$ & 81,019 & 134,471 \\
\hline
\end{tabular}

\section{B.2. Energy and carbon dioxide intensity for electric arc furnace and blast furnace/basic oxygen furnace production in Mexico}

Mexico's official energy data for iron and steel production (SENER 2012) are not disaggregated by production route. To address this issue, we calculated the energy intensities of the different production routes based on other previous studies by Kirschen et al. (2011) for 16 DRI- and scrap-based international EAF plants working under average conditions. The information from that study was adjusted to the Mexican case using our industry boundary definition. 
Table B.2 shows the information obtained from Kirschen et al. (2011). The EAF operation parameters in the first column (inputs in physical units) represent the average of 16 international industrial EAFs, including furnaces of the Mexican steel manufacturer Ternium-Hylsa.

Table B.2. EAF scrap-based and DRI-based materials usage ratios

\section{Inputs in physical units}

\begin{tabular}{lrr} 
& Scrap-based & DRI-based \\
\hline DRI, t/tcs* & 0 & 0.8 \\
Lime, $\mathrm{kg} / \mathrm{tcs}$ & 34 & 60 \\
Coal, $\mathrm{kg} / \mathrm{tcs}$ & 17 & 23 \\
Oxygen, $\mathrm{m}^{3} / \mathrm{tcs}$ & 32 & 28 \\
Nat gas, $\mathrm{m}^{3} / \mathrm{tcs}$ & 5 & 1.5 \\
Electricity, $\mathrm{kWh} / \mathrm{tcs}$ & 391 & 570 \\
\hline \multicolumn{3}{c}{ *tcs: metric tons of crude steel } \\
\multicolumn{3}{c}{ Source: Kirschen et al. 2011 }
\end{tabular}

Because there are no previous studies of BF/BOF process energy use in Mexico, we calculated the energy intensity of this process using the overall energy intensity and EAF intensity with the following equation:

Where:

$$
E I_{B F / B O F}=\frac{E I_{C S}-\% E A F * E I_{E A F}}{\% B F / B O F}
$$

\footnotetext{
$\mathrm{EI}_{\mathrm{BF} / \mathrm{BOF}}$ : final energy intensity of the $\mathrm{BF} / \mathrm{BOF}$ production process in Mexico in 2010

$\mathrm{EI}_{\mathrm{CS}}$ : final energy intensity of the overall iron and steel process

\%EAF: share of crude steel produced by the EAF route in Mexico in 2010.

$\mathrm{EI}_{\mathrm{EAF}}$ : final energy intensity of the EAF process in Mexico.

$\% \mathrm{BF} / \mathrm{BOF}$ : share of the crude steel produced by the BF/BOF production route in Mexico in 2010.
}

\section{B.3. Uncertainties in the calculation of carbon dioxide intensities for Mexico's steel industry}

Two main uncertainties associated with our calculations are:

First, the actual energy consumed in ferro-alloy manufacturing in Mexico might be different than we calculated because industry conditions vary. However, the possible error range does not have an important effect on our results because ferro-alloy manufacturing accounts only for about $3 \%$ of final energy use in Mexico.

Second, as mentioned above, Mexico does not collect the statistical information needed break down the energy consumption into the two steel production routes (BF-BOF and EAF); therefore, as explained, we took EAF energy and materials use data from a previous study by Kirschen et al. (2011). Another element of uncertainty is our $\mathrm{CO}_{2}$ intensity estimation. Because there is no information on the energy consumption by production route, we assumed that EAF plants in Mexico use mostly natural gas as fuel for purposes of estimating fuel emissions by production route. This assumption was made due to the fact that there is no pig iron consumed in the EAFs in Mexico and that EAFs feedstocks were 45\% DRI and 55\% Scrap in 2010. 